\title{
IMPLEMENTASI EMPOWERMENT DALAM MENINGKATKAN KINERJA KARYAWAN
}

\author{
Onsardi \\ Dosen Universitas Muhammadiyah Bengkulu \\ onsardi@umb.ac.id
}

\begin{abstract}
Abstrak
Tujuan penulisan makalah ini (1) Untuk melihat implementasi empowerment pada Universitas Muhammadiyah Bengkulu, (2) Untuk melihat kinerja karyawan pada Universitas Muhammadiyah Bengkulu dan (3) Untuk melihat implementasi empowerment dalam upaya meningkatkan kinerka karyawan pada Universitas Muhammadiyah Bengkulu. Metode yang digunakan studi pustaka. Kesimpulan makalah ini adalah Implementasi empowermen di Universitas Muhammadiyah Bengkulu sudah dilakukan cukup baik. Kinerja Karyawan sudah cukup baik. Empowermen dapat meningkatkan kinerja karyawan jika dilakukan dengan sungguhsungguh baik dan benar.
\end{abstract}

Keywords : Empowerment, Kinerja Karyawan

\section{BAB I \\ PENDAHULUAN}

\section{A. Latar Belakang Masalah}

Dalam menghadapi persaingan yang semakin ketat dewasa ini, sangat diperlukan adanya sumber daya manusia (SDM) yang berkualitas sehingga mampu menghadapi persaingan dan perubahan (Sariyanthi, 2007). Kualitas sumber daya manusia saat ini tengah menjadi fokus utama berbagai kajian dalam bidang manajemen organisasi karena sumber daya manusia merupakan faktor yang membedakan antara negara yang berkembang dari negara yang belum berkembang (Fard, A. Rajabzadeh, 2010). Oleh karena itu, peningkatan kualitas sumber daya manusia sebagai pelaku pembangunan sangat strategis. Hal ini didasarkan pada tujuan pembangunan Indonesia antara lain untuk membentuk manusia yang berkualitas,

Sumber daya manusia merupakan salah satu faktor dalam meningkatkan kinerja suatu organisasi atau instansi. Peningkatan kinerja sangat ditentukan oleh SDM yang mempunyai komitmen yang tinggi, keahlian atau kompetensi, dan budaya organisasi yang baik, serta kemampuan kerja yang dapat mendukung kepuasan kerja. 
Menurut Timpe, bahwa pegawai yang memiliki job performance yang tinggi adalah pegawai yang produktif. Pegawai yang produktif memiliki ciri sebagai berikut: (1) memiliki kecerdasan pikiran dan dapat mempelajari kondisi sekitar dengan cepat, (2) memiliki kompetensi secara profesional, (3) memiliki daya kreatifitas dan inovatif yang tinggi, (4) memahami dan menguasai pekerjaannya, (5) belajar dengan cerdik, menggunakan logika, dan mengorganisir pekerjaan dengan efisien, (6) selalu berusaha untuk melakukan perbaikan, (7) dianggap bernilai oleh pengawasnya, (8) memiliki prestasi yang baik dan (9) selalu berusaha untuk meningkatkan kemampuan kerja (Tempe, 2000). Namun kenyataannya, harapan mengenai kualitas sumber daya manusia yang berkualitas, yang tercermin pada kinerja setiap pegawai masih jauh dari harapan.

Pemberian empowermen kepada pengawai adalah salah satu langkah untuk meningkatkan kinerja karyawan, karena empowermen merupakan suatu kepacayaan yang diberikan atasan kepada bawahan secara penuh dengan harapan karyawan itu dapat secara bertanggungjawab untuk melaksanakan tugas yang dipecayakan peada dia. Hal ini sesuai dengan pendapat Duvall (1999) mendefinisikan sukses sebagai prestasi dan pencapaian yang merupakan konsekuensi dari pemberdayaan. Ia mengungkapkan bahwa pencapaian prestasi ini juga berupa keberhasilan pemberdayaan melalui: (1) Jaringan keberhasilan dalam bentuk kinerja peran karyawan. (2) Sukses organisasi yang dicapai anggota organisasi meliputi kumpulan tujuan dan sasaran organisasi. (3) Anggota organisasi yang bertemu dan saling berbagi manfaat pengalaman dan kepuasan kerja yang berguna bagi pertumbuhan kelompok maupun individu.

Kinerja karyawan adalah salah satu kunci yang penting bagi organisasi ataupun perusahaan sebab setiap perusahaan tidak dapat mengalami peningkatan hanya dari upaya satu atau dua orang saja, melainkan dari keseluruhan upaya anggota perusahaan. Organisasi yang dapat menghasilkan kinerja yang baik tentu tidak terlepas dari hasil kinerja yang dicapai oleh anggota-anggotanya. Untuk itu organisasi harus dapat mengkoordinir setiap anggotanya dalam pencapaian kinerja yang optimal.

Kinerja menjadi bagian penting dalam kehidupan organisasi. Menurut Prabu Mengkunegara (2013) kinerja adalah hasil kerja secara kualitas dan 
kuantitas yang dicapai oleh seorang pegawai dalam melaksanakan tugasnya sesuai dengan tanggung jawab yang diberikan kepadanya. Berdasarkan penelitian yang dilakukan oleh Qaisar Abbas dan Sara Yaqoob (2009) kinerja karyawan dapat ditingkatkan melalui faktor- faktor pengembangan kepemimpinan yakni, harus dapat menerapkan faktor-faktor pengembangan kepemimpinan diatas dalam rangka meningkatkan kinerja karyawan sekaligus mengarahkan kinerja karyawan sesuai sasaran strategis perusahaan atau organisasi.

Perusahaan senantiasa menginginkan agar kinerja karyawannya baik, dengan demikian untuk meningkatkan kontribusi para karyawan kepada organisasinya, maka organisasi perlu menerapkan program pemberdayaan. Beberapa pakar manajemen, sepakat menyatakan bahwa pemberdayaan akan mendapatkan manfaat dan keuntungan bagi organisasi (Holosko et al., 2001). Pemberdayaan dianggap mampu menumbuhkan dan meningkatkan kreativitas para karyawan. Sedangkan kreativitas sendiri merupakan landasan bagi tumbuh berkembangnya inovasi. Karyawan yang memiliki kreativitas akan selalu mencari cara atau metode baru yang murah dan tepat dalam upaya untuk menghasilkan suatu produk yang berkualitas atau dalam memberikan pelayanan yang memuaskan kepada pelanggannya. Karyawan yang kreatif juga memberikan andil yang besar bagi terciptanya inovasi produk suatu organisasi. Oleh karena itu, pemberdayaan dipandang menjadi bagian yang penting dalam rangka menjamin kelangsungan hidup organisasi dalam lingkungan yang kompetitif.

Pemberdayaan dilakukan di dalam organisasi dilakukan di dalam organisasi dengan fokus pada penyediaan produk dan jasa pelayanan. Melalui konsep ini, karyawan diberi wewenang dan tanggung jawab yang lebih besar dalam mengambil keputusan. Untuk itu dibutuhkan komunikasi atau saling tukar menukar informasi dan pengetahuan antara pimpinan dan karyawan sehingga para karyawan dapat benarbenar memahami tugasnya dan dapat memberikan kontribusi yang nyata pada pencapaian prestasi organisasi.

Berdasar latar belakang masalah di atas, maka penulis tertarik untuk mengkaji tentang implementasi Empowerment dalam upaya meningkatkan kinerja karyawan pada Universitas Muhammadiyah Bengkulu. 


\section{B. Rumusan Masalah}

Dari latar belakang masalah di atas, maka yang menjadi rumusan masalah dalam tulisan ini adalah "Bagaimanakah Implementasi Empowerment dalam meningkatkan kinerja Karyawan pada Universitas Muhammadiyah Bengkulu?.

\section{Tujuan Penulisan}

1. Untuk melihat implementasi empowerment pada Universitas Muhammadiyah Bengkulu.

2. Untuk melihat kinerja karyawan pada Universitas Muhammadiyah Bengkulu.

3. Untuk melihat implementasi empowerment dalam upaya meningkatkan kinerka karyawan pada Universitas Muhammadiyah Bengkulu.

\section{BAB II.}

\section{KAJIAN TEORI}

\section{A. Kinerja}

Istilah "kinerja berasal dari pengertian performance. Ada pula yang memberikan pengertian perfonnance sebagai hasll kerja atau prestasi kerja. Namun sebenarnya kinerja mempunyal makna yang lebih luas, bukan hanya hasH kerja, tetapi termasuk bagaimana proses pekerjaan berlangsung. Pengertian lain kata "kinerja" dalam bahasa Indonesia adalah terjemahan dari kata dalam bahasa Inggris "perfonnance" yang berarti; (1) pekerjaan, perbuatan atau (2) penampilan, pertunjukan.

Sedangkan kinerja dalam istilah ilmu administrasi atau ilmu manajemen memiliki pengertian yang hampir sama. Lebih lanjut, menurut Sagala memberikan pengertian bahwa performans berasal dari bahasa Inggris "performance" yang berarti unjuk kerja atau kinerja, namun terminologi ini telah di Indonesiakan menjadi pertormans. Dengan demikian yang dimaksud dengan kinerja adalah unjuk kerja yang diperlihatkan dalam mengerjakan sesuatu pekerjaan secara individu atau kelompok dalam suatu institusi atau organisasi, sesuai dengan wewenang dan tanggung jawab masing-masing dalam mencapai tujuan institusi atau organisasi. Kinerja yang diharapkan merupakan tujuan akhir dari suatu kegiatan yang dilakukan oleh institusi atau organisasi. Kinerja itu dapat 
berbentuk kinerja rnanejernen (managerial performance) dan kinerja individu (employee performance).

Kinerja didefinisikan Colquitt (2009) sebagai "the value of the set of employee behaviors that contribute, either positively or negatively, to organizational goal eccompiisnment". Nilai dari seperangkat perilaku karyawan yang berkontribusi, baik secara positif atau negatif terhadap pemenuhan tujuan organisasi. Menurutnya kinerja ditentukan oleh tiga faktor yaitu: 1) kinerja tugas (task performance) dipengaruhi oleh faktor rutinitas dan adaptasi, 2) perilaku kesetiaan (citizenship behavior) dipengaruhi oleh faktor interpersonal dan faktor organisasional, 3) perilaku produktif tandingan (counter productive behvior) dipengaruhi oleh faktor deviasi sifat, faktor deviasi produksi, faktor deviasi politik dan faktor agresi personal.

Luthans (2008), mengemukakan "People generally have in intense desire to know how they are doing, they engage in feedback-seeking behavior. Even though feedback has been found to be complex in research studies. It is generally accepted that feed back enhances individual performance ibehavioral meneqemenr". Pandangan tersebut menunjukkan sebagai harapan yang kuat untuk mengetahui bagaimana kerja mereka dan terlibat dalam perilaku umpan balik yang dapat memajukan kinerja individu dalam manajemen perilaku.

Menurut Kondalkar (2007), "The level of performance will generally depend upon role perception as defined in the standing orders/policy instructions, the level of efforts, skills, ability, knowledge, and intellectual capacity of the lnoividuel". Pandangan tersebut menunjukkan bahwa tingkat kinerja akan tergantung pada persepsi peran seperti ditentukan dalam peraturan kebijakan, tingkat upaya, keterampilan, kemampuan kerja, pengetahuan dan kapasitas intelektual dari individu.

Menurut Ivancevich (2008), "Job performance includes a numbers of outcomes. In this section we will discuss performance outcome that have velue to the organizational and to the lndividuet". Kinerja pekerjaan meliputi sejumlah hasil yang mempunyai nilai pada organisasi dan individu. Setiap perilaku diasosiasikan dengan hasil tertentu. Seseorang yang bekerja dengan perilaku tertentu, akan memperoleh sesuatu yang bernilai bagi organisasi maupun individu. Hal ini sudah merupakan deskripsi dari kinerja dan hasil. 
Sedang menurut Amstrong (2006), "Performance management can be defined as a systematic process for improving organizational performance by developing the performance of individuals and teams". Ungkapan tersebut menunjukkan bahwa kinerja manajemen merupakan satu proses sistematis untuk meningkatkan kinerja organisasi dengan cara mengembangkan kinerja individu dan tim.

Harsey, Blanchard dan Johnson (1996) menyatakan bahwa kinerja adalah hasil dari suatu aktlvitas pekerjaan." Hal ini sejalan dengan apa yang dikemukakan oleh Milkovich dan Boudreau yaitu; "Performance refflects the organization's success. Employee performance is the degree to which employees accomplish work requirement". Dari pendapat tersebut terlihat bahwa kinerja pegawai dapat dilihat dari hasil pekerjaan yang ditetapkan. Pandangan lain dikemukakan oleh Benardin dan Russel (1998) yang menyatakan, "Performance is defined as the record of outcome produced on a specified job function or activity during a specified time period". Pandangan tersebut memperlihatkan bahwa kinerja merupakan sebuah catatan dari sebuah outcome suatu pekerjaan yang dihasilkan dalam jangka waktu tertentu.

Menurut Jennifer M. George \& Gareth R. Jones (2005) kinerja adalah "Performance is an evaluation of the results of a person's behavior: it involves determining how well or poorly a person has accomplished a task or done ajob". Kinerja merupakan sebuah evaluasi hasll terhadap sikap seseorang termasuk menentukan bagus tidaknya pekerjaan seseorang yang sudah dikerjakan. Apabila seseorang dapat menyelesaikan tugas-tugas yang diberikan kepadanya melebihi standar yang telah ditetapkan, berarti kinerjanya baik.

Pendapat diatas suatu konsep yang dapat dijadikan acuan untuk mengukur kinerja pegawai, yakni:

1. Kuantitas pekerjaan, seberapa banyak tingkat menyelesaikan masalah dari sejumlah program yang ada dengan tetap memprioritaskan terhadap masalah yang harus segera diselesaikan. Ukuran kinerja dapat dinyatakan dalam bentuk jumlah output dan prosentase antara output aktual dengan output yang menjadi target.

2. Kualitas pekerjaan, dapat dilihat dari segi ketelitian dan kerapihan dalam bekerja, kecepatan menyelesaikan tugas, keterampilan dan kecakapan kerja. Ukuran kinerja dinyatakan dalam membentuk kualitas yang bervariasi di 
luar batas, jumlah keluhan yang masih dalam batas yang dapat dipertimbangkan untuk ditoleransi.

3. Kemampuan kerja, dapat berarti kecepatan dan semakin berkurangnya masalah dalam setiap menyelesaikan tugas. Ukuran kinerja dapat dinyatakan perbandingan waktu dengan tugas dan jumlah masalah yang ada.

4. Kehadiran ditempat kerja, keberadaannya ditempat tugas dan tempat yang berkaitan, kedisiplinan dalam tugas, kedisiplinan dalam mentaati peraturan yang telah dibuat. Ukuran kinerja dapat dinyatakan dalam bentuk pencapaian batas waktu penyelesaian tugas.

5. Kehandalan pemberian pelayanan, kesediaan untuk memberikan bantuan ketika diperlukan penyelesaian masalah oleh semua personil maupun masyarakat yang berkaitan dengan pelayanan publik.

6. Fleksibilitas, mudah menyesuaikan dengan berbagai situasi yang dihadapi, baik dalam suasana pembelajaran di sekolah maupun di luar.

Berdasarkan uraian tersebut di atas maka dapat disentesiskan bahwa yang dimaksud dengan kinerja adalah suatu unjuk kerja seseorang dalam melaksanakan tugas dan tanggung jawabnya untuk mencapai tujuan organisasi, dengan indikator-indikator; rutinitas dalam bekerja, rasa suka menolong, fleksibel terhadap pekerjaan, pengakuan atas hasil kerja.

\section{B. Pemberdayaan}

\section{Pengertian Empowerment}

Pemberdayaan (empowerment) secara etimologis berasal dari kata daya yang berarti kemampuan untuk melakukan sesuatu atau kemampuan bertindak. Mendapat awalan ber - menjadi 'berdaya' artinya berkekuatan, berkemampuan, bertenaga, mempunyai akal (cara dan sebagainya) untuk mengatasi sesuatu (Suwatno dan Priansa, 2011). Sedangkan Khan (2007, dalam Suwatno dan Priansa, 2011) menjelaskan pemberdayaan merupakan hubungan antar personal yang berkelanjutan untuk membangun kepercayaan antar karyawan dan manajemen. Pemberdayaan karyawan (employee empowerment) menurut Mulyadi (2007) merupakan tren pengelolaan modal manusia di dalam organisasi masa depan, sedangkan menurut Pradiansyah (2002) pemberdayaan merupakan kepercayaan (trust). Jadi secara garis besar pemberdayaan merupakan upaya yang dilakukan perusahaan dalam 
memberikan wewenang dan kepercayaan lebih kepada karyawan agar karyawan lebih leluasa dalam mengeluarkan segala kemampuan yang ada pada dirinya.

Pemberdayaan merupakan pelibatan karyawan yang benar-benar berarti. Pemberdayaan atau (empowerment), adalah wewenang untuk membuat keputusan dalam suatu area kegiatan operasi tertentu tanpa harus memperoleh pengesahan orang lain (Luthans, 1998). Sedangkan Straub (1989; dalam Sadarusman, 2004), mengartikan pemberdayaan sebagai pemberian otonomi, wewenang, kepercayaan, dan mendorong individu dalam suatu organisasi untuk mengembangkan peraturan dalam rangka menyelesaikan pekerjaan. Pemberdayaan merupakan pemberian tanggung jawab dan wewenang terhadap pekerja untuk mengambil keputusan menyangkut semua pengembangan produk dan pengambilan keputusan. Pemberdayaan juga berarti saling berbagi informasi dan pengetahuan diantara karyawan yang digunakan untuk memahami dan mendukung kinerja organisasi, pemberian penghargaan terhadap kinerja aorganisasi dan pemberian otonomi dalam pengambilan keputusan yang berpengaruh terhadap organisasi (Ford 1995; dalam Sadarusman, 2004).

Pemberdayaan merupakan sarana membangun kepercayaan antara karyawan dan manajemen. Ada dua karakteristik dalam pemberdayaan, bahwa karyawan didorong untuk menggunakan inisiatif mereka sendiri, dan karyawan tidak hanya hanya diberi wewenang saja tetapi juga diberi sumberdaya untuk melakukan pengambilan keputusan sesuai dengan kreativitas dan inovasi mereka. Secara tidak langsung karyawan juga didorong untuk melakukan pembelajaran dari hasil keputusan dan pelaksanaannya. Tujuan pemberdayaan tidak hanya untuk menjamin efektivitas keputusan yang dibuat oleh karyawan yang benar tetapi juga digunakan untuk menyediakan mekanisme dan tanggung jawab dari keputusan individu atau tim.

Thomas dan Veltahouse (1990) beragumentasi bahwa pemberdayaan merupakan suatu yang multifaceted yang esensinya tidak bisa dicakup dalam satu konsep tunggal. Dengan kata lain pemberdayaan mengandung pengertian perlunya keleluasaan kepada individu untuk bertindak dan sekaligus bertanggung jawab atas tindakannya sesuai dengan tugas yang diembannya. Konsep pemberdayaan ini juga berarti bahwa seseorang akan mampu untuk berperilaku secara mandiri dan penuh tanggung jawab. Konsep pemberdayaan dari Thomas dan Velthouse ini dimanifestasikan dalam empat kognisi yang merefleksikan orientasi individu atas 
peran kerjanya yaitu arti (meaning), kompetensi (competence), pendeterminasian diri (self determination), dan pengaruh (impact).

Dari penelitian Spreitzer (1986; dalam Mahardiani, 2004) ditemukan empat karakteristik umum yang dimiliki empowered people yang juga sama dengan konsep Thomas dan Velthouse (1990), yaitu:

\section{a. Sense of meaning}

Meaning merupakan nilai tujuan pekerjaan yang dilihat dari hubungannya pada idealisme atau standar individu.

b. Sense of competence

Kompetensi atau self efficacy lebih merupakan kepercayaan individu akan kemampuan mereka dalam melakukan aktivitas mereka dengan menggunakan keahlian yang mereka miliki. Dimensi ini menggunakan istilah kompetensi daripada self esteem karena difokuskan pada efficacy secara spesifik pada peran pekerjaan.

\section{c. Sense of determination}

Bila kompetensi merupakan keahlian dalam berperilaku, maka self determination merupakan suatu perasaan memiliki suatu pilihan dalam membuat pilihan atau melakukan suatu pekerjaan.

d. Sense of impact

Impact atau dampak merupakan derajat dimana seseorang dapat memengaruhi hasil pekerjaan baik stratejik, administratif

Khan (1997) menawarakan sebuah model pemberdayaan yang dapat dikembangkan dalam sebuah organisasi untuk menjamin keberhasilan proses pemberdayaan dalam suatu organisasi. Model pemberdayaan tersebut yaitu:

\section{Desire}

Tahap pertama dalam model empowerment adalah adanya keinginan dari manajemen untuk mendelegasikan dan melibatkan pekerja.Yang termasuk hal ini antara lain:

a. Pekerja diberi kesempatan untuk mengidentifikasikan permasalahan yang sedang berkembang.

b. Memperkecil directive personality dan memperluas kesempatan kerja.

c. Mendorong terciptanya perspektif baru dan memikirkan kembali strategi kerja. 
d. Mengembangkan keahlian team dan melatih karyawan untuk mengawasi sendiri (self control).

\section{Trust}

Tahap dua adalah membangun kepercayaan antara manajemen dan karyawan Adanya saling percaya di antara anggota organisasi akan tercipta kondisi yang baik untuk pertukaran informasi dan saran tanpa adanya rasa takut. Hal-hal yang termasuk dalam trust antara lain:

a. Memberi kesempatan kepada para karyawan untuk berpartisipasi dalam pembuatan kebijakan.

b. Menyediakan waktu dan sumber daya yang mencukupi bagi karyawan dalam menyelesaikan kerja.

c. Menyediakan pelatihan yang mencukupi bagi karyawan bagi kebutuhan kerja.

d. Menghargai perbedaan pandangan dan menghargai kesuksesan yang diraih oleh karyawan.

e. Menyediakan akses informasi yang cukup.

\section{Confident}

Tahap ke tiga dalam proses pemberdayaan adalah menimbulkan rasa percaya diri karyawan dengan menghargai terhadap kemampuan yang dimiliki oleh karyawan. Hal yang termasuk tindakan yang menimbulkan confident antara lain:

a. Mendelegasikan tugas yang penting kepada karyawan

b. Menggali ide dan saran dari karyawan.

c. Memperluas tugas dan membangun jarungan antar departemen

d. Menyediakan jadwal job instruction dan mendorong penyelesaian yang baik.

\section{Credibility}

Tahap ke empat berupa menjaga kredibilitas dengan penghargaan dan mengembangkan lingkungan kerja yang sehat sehingga tercipta organisasi yang memiliki performance yang tinggi. Hal yang termasuk credibility adalah:

a. Memandang karyawan sebagai partner strategis

b. Peningkatan target di semua pekerjaan. 
c. Memperkenalkan inisiatif individu untuk melakukan perubahan melalui partisipasi.

d. Membantu menyelesaikan perbedaan dalam penentuan tujuan dan prioritas.

\section{Accountabiliy}

Tahap dalam proses pemberdayaan berikutnya adalah pertanggungjawaban karyawan pada wewenang yang diberikan. Dengan menetapkan secara konsisten dan jelas tentang peran, standar dan tujuan penilaian terhadap kinerja karyawan, tahap ini merupakan sarana evaluasi terhadap kinerja dalam penyelesaian dan tanggung jawab terhadap wewenang yang diberikan. Hal yang termasuk dalam accountability antara lain:

a. Menggunakan jalur training dalam mengevaluasi kinerja karyawan.

b. Memberikan tugas dan ukuran yang jelas.

c. Melibatkan karyawan dalam penentuan standar dan ukuran.

d. Memberikan saran dan bantuan kepada karyawan dalam menyelesaikan beban kerjanya.

e. Menyediakan periode dan waktu pemberian feedback.

\section{Communication}

Tahap ini merupakan tahap terakhir, diharapkan adanya komunikasi yang terbuka untuk menciptakan saling memahami antara karyawan dengan manajemen. Keterbukaan ini dapat diwujudkan dengan adanya kritik dan saran terhadap hasil dan prestasi yang dilakukan pekerja. Hal yang termasuk dalam commnication antara lain:

a. Menetapkan kebijakan open door communication.

b. Menyediakan waktu untuk mendapatkan informasi dan mendiskusikan permasalahan secara terbuka.

c. Menyediakan kesempatan untuk cross training. maupun operasional.

\section{Strategi Pemberdayaan}

Menurut Suwatno dan Donni Juni Priansa (2011) strategi dalam pemberdayaan pegawai didasarkan atas delapan buah langkah menuju keberhasilan, yaitu :

1. Hubungan dengan visi 
Hubungkan empowerment dengan visi dan misi dan nilai organisasi sehingga empowerment menjadi bagian dari organisasi.

2. Diarahkan dengan menggunakan contoh-contoh

Empowerment harus dilihat dari sudut pandang bahwa dia datang dari manajemen teratas, dimana para pemimpin dapat memberikan visi untuk masa mendatang dan memberikan dukungan serta dorongan yang sangat penting untuk menciptakan suatu lingkungan dimana orang-orang bertanggung jawab terhadap nasib mereka sendiri.

3. Berkomunikasi secara aktif

Yaitu dengan melibatkan karyawan didalam komunikasi dan pembahasan umpan balik secara tetap, maka organisasi dapat mendorong terjadinya empowerment.

4. Meninjau struktur organisasi

Empowerment yang berhasil memerlukan perubahan yang terjadi didalam struktur, sehingga para individu menjadi lebih dekat kepada titik keputusan, dan birokrasi dapat dibuang melalui rantai pengawasan yang lebih kecil

5. Menguatkan kerja tim

Empowerment membutuhkan dukungan kerja tim yang memiliki empowerment adalah salah satu mekanisme terkuat untuk menyediakan suatu lingkungan bagi pengambilan inisiatif dan kadang-kadang berbuat kesalahan tapi juga untuk belajar darinya.

6. Mendorong pengembangan pribadi

Yaitu dengan memberikan bantuan dan dorongan untuk membentuk rasa percaya diri agar staf dapat membuat keputusan sendiri.

7. Menjadikan jasa layanan kepada pelanggan sebagai fokus

Hasil akhir empowerment adalah berupa naiknya tingkatan jasa layanan kepada pelanggan, sehingga karyawan yang berada di garis depan dan karyawan yang berhubungan dengan pelanggan internal harus didorong untuk bertanggung jawab memuaskan pelanggan mereka. 
8. Ukur perkembangan yang terjadi dan kenali serta hargai keberhasilan

Organisasi perlu menentukan ukuran keberhasilan dan membantu agar ukuran ini dapat dipahami oleh setiap orang, dengan membuat atau menentukan cara agar keberhasilan individu dapat dikenali.

\section{Proses Pemberdayaan}

Menurut Sedarmayanti (2000) pemberdayaan pegawai merupakan cara yang amat praktis dan produktif untuk mendapatkan yang terbaik dari diri kita dan dari staf kita terdapat tiga proses dalam memberdayakan pegawai, yaitu sebagai berikut:

1. Menciptakan suasana yang memungkinkan potensi manusia berkembang, titik tolaknya adalah pengenalan bahwa setiap manusia memiliki potensi yang dapat dikembangkan, pemberdayaan adalah membangun daya itu dengan mendorong, membangun dan membangkitkan kesadaran akan potensi yang dimiliki serta berupaya untuk mengembangkannya.

2. Memperkuat potensi yang dimiliki manusia, upaya ini meliputi langkah nyata, dan menyangkut penyediaan berbagai masukan serta pembukaan pada berbagai peluang yang membuat manusia menjadi berdaya dan upaya utamanya adalah peningkatan taraf pendidikan, derajat kesehatan, dan akses pada sumber-sumber kemajuan ekonomi.

3. Proses pemberdayaan harus dicegah dari yang lemah menjadi bertambah kuat oleh karena berkurang berdayaannya dalam menghadapi yang kuat, dan perlu adanya peraturan perundangan yang secara jelas melindungi guna melindungi yang lemah.

\section{Tujuan Pemberdayaan}

Tujuan dari pemberdayaan pegawai adalah untuk memperbaiki efektifitas kerja pegawai dalam mencapai hasil - hasil kerja yang telah ditetapkan. Perbaikan efektifitas kerja tersebut dapat dilakukan dengan cara memperbaiki pengetahuan dan keterampilan pegawai maupun sikap pegawai itu sendiri terhadap tugas - tugasnya Suad Husnan, 1991 (dalam Sartono, 2011).

Sedangkan menurut Manulang, (dalam Sartono, 2011) mengemukakan bahwa tujuan pemberdayaan pegawai adalah untuk menambah pengetahuan, menambah keterampilan dan merubah sikap. Selanjutnya menurut Dale Yoder, Alfred Laitener 
dan Joseph Triffin (dalam Sartono, 2011) tujuan pemberdayaan pegawai pada umumnya adalah :

1. Supaya pegawai dapat melakukan pekerjaan dengan lebih efisien. Dengan diadakan suatu pemberdayaan yang disusun secara cermat dan didasarkan pada metode yang berpedoman pada keterampilan yang dibutuhkan diharapkan dapat melaksanakan pekerjaan dengan lebih efisien.

2. Supaya pengawasan lebih sedikit dilakukan terhadap pegawai. Pemberdayaan pegawai yang berpedoman pada keterampilan di harapkan menghasilkan pegawai yang cakap dan keterampilan akan dapat bekerjaan lebih efektif dan efisien yang mana akan berdampak pada berkurangnya pengawasan yang dilakukan oleh atasan.

3. Supaya pegawai lebih cepat berkembang. Dengan adanya pemberdayaan pegawai, salah harapan adalah hasil kerja yang lebih baik dan prestasi pegawai yang meningkat, maka adanya daya saing akan makin besar. Dengan demikian tujuan organisasi dapat tercapai.

\section{Fungsi Empowerment}

Menurut Sondang P.Siagian (2001) dalam menyelenggarakan fungsinya para anggota organisasi harus berdaya yaitu :

a. Diperlakukan sebagai orang yang memiliki rasa tanggung jawab yang besar.

b. Diajak serta dalam pengambilan keputusan, bukan hanya yang menyangkut pekerjaan dan jabatannya akan tetapi juga meliputi berbagai kehidupan organisasional pada umumnya.

c. Melakukan pekerjaan yang menarik, menantang dengan identitas yang jelas.

d. Adanya kebebasan bertindak menyusun rencana, menentukan sasaran, menyusun jadwal penyelesaian pekerjaan, menentukan sendiri cara penyelesaian masalah yang dihadapi.

e. Kesempatan mengembangkan potensi yang dimiliki menjadi kemampuan aktual operasional yang efektif, sehingga kinerja meningkat.

\section{Pendekatan Psikologika Pemberdayaan (Psycological Empowerment)}

Pemberdayaan menurut Curson dan Enz (1999) diukur melalui 3 dimensi, yaitu : 
1) Personal Influence ( pangaruh pribadi); yaitu sejauhmana individu memiliki pilihan yang berkenaan dengan perilaku mereka sendiri. Karyawan merasa yakin bahwa apa yang didapat melalui pihaknya sangat berpengaruh terhadap organisasi. Personal Influence dapat dilakukan dengan determinasi diri yang direfleksikan dalam proses kerja yang menghasilkan pembelajaran dan mempengaruhi strategi serta mengoperasionalkan hasil-hasil dalam pekerjaan.

2) Self Efficacy (Keefektifan diri); yaitu sejauhmana karyawan mempunyai keyakinan untuk melaksanakan kerja secara tuntas. Perasaan ini berdasar pada kenyakinan individu bahwa dia mampu melaksanakan aktivitas kerja dengan keterampilan dan berhasil dianggap sebagai tugas yang spesifik. Penilaian untuk dimensi ini mencakup persepsi karyawan bahwa keterampilan diperlukan untuk keberhasilan dalam kerja dan menuju kesuksesan.

3) Meaningfulness (makna kerja); karyawan menilai makna kerja bahwa mereka peduli apa yang mereka kerjakan. Menilai sejauh mana karyawan menemukan pemenuhan dalam apa yang mereka kerjakan.

Thomas \& Velthoust (1990) dalam Gretchhen M.Spreitzer (1995) mendefinisikan Psycological Empowerment sebagai motivasi intrinsik dalam menjalankan tugas (intrinsic task motivation) yang ditanamkan pada 4 kesadaran (cognition) yang mencerminkan orientasi individu terhadap pekerjaannya, yaitu;

1) Keberartian (meaningfulness)

2) Kemampuan (competence) atau keyakinan diri (self efficacy)

3) Pilihan atau penentuan sendiri (choice or determination)

4) Pengaruh yang kuat (impact)

Meaning adalah sebuah dimensi dari model karakteristik kerja, yaitu kesesuaian antara aturan kerja dengan nilai-nilai yang ia percaya serta perilakunya (Thomas \& Velthouse, 1990). Rasa keberartian (meaning) termasuk dalam syarat pada aturanaturan kerja dan diyakini, ni-nilai pada perilaku (Brief \& Nord, 1990), (Hackman \& Oldham, 1980).Competence atau self efficacy khususnya pada kerja seseorang adalah kepercayaan terhadap kemampuan dalam bekerja dengan keahlian (Gist, 1987). Competence merupakan kenyakinan individu yang dimiliki. Menurut Bandura (1989), Kompetensi adalah analog dengan penguasaan personal, keyakinan, atau 
ekspektensi usaha performa. Semakin tinggi self-efficacy seseorang semakin percaya diri ia terhadap keberhasilan tugasnya. Makin tinggi self-efficacy seseorang, makin banyak kepercayaan diri yang dipunyai terhadap kemampuannya untuk berhasil dalam suatu tugas.

Self Determination adalah determinasi diri merupakan sense atau rasa individual dalam melihat tindakan awal dan regulasi (Deci, Conel \& Ryan, 1989). Seseorang dengan self determination yang rendah merasa kurang berkuasa dan konsekuensinya dia mempunyai kontrol yang kecil terhadap lingkungannya.

Impact adalah tingkatan di mana seseorang dapat mempengaruhi strategi, pengelolaan maupun pengoperasian hasil kerja (Ashfort, 1989). Impact menyatakan bahwa memahami kekuasaan dan pengaruh dalam organisasi penting bagi seseorang untuk mendapatkan sesuatu dapat terlaksana dalam organisasi. Individu yang mempelajari dan melatih penggunaan kekuasaan melalui berbagai taktik mempengaruhi apa yang diinginkannya.

Dalam pemberdayaan karyawan perlu adanya lingkungan kerja yang membentuk sikap dan perilaku para pekerja atau karyawan kearah positif maupun negatif. Kehidupan karyawan sehari-hari adalah menjalin hubungan dengan konsumen, organisasi, dan rekan kerjanya.

Lingkungan kerja yang kondusif dicirikan dengan tolong - menolong, partisipasi, kepercayaan, dan keterlibatan yang mempunyai pengaruh pada pemberdayaan karyawan. Setiap orang menghargai "rasa kebersamaan" dan kerjasama dengan rekan kerja.Jika karyawan bekerja dalam lingkungan yang kondusif, maka karyawan akan lebih diberdayakan. Jadi, pemberdayaan pada prinsipnya membantu organisasi lebih unggul dipasar sekarang dan masa mendatang.

\section{Manfaat Pemberdayaan}

Mengapa suatu organisasi perlu melakukan pemberdayaan? Cluuterbuck dan Kernaghan (2000) menyebutkan sejumlah manfaat yang dapat diperoleh organisasi dengan melakukan pemberdayaan pegawai mereka:

1) Quality, Kebanyakan organisasi merasa harus melakukan perbaikan terus menerus untuk dapat kompetitif. Untuk dapat terus menerus melakukan perbaikan, 
maka yang dapat dilakukan adalah get people to own their job, dan untuk itu dibutuhkan pemberdayaan untuk memotivasi mereka.

2) Innovation, transfer kekuasaan yang dilakukan melalui pemberrdayaan akan menciptakan kreativitas karyawan, karena karyawan memiliki kebebasan dalam menyelesaikan tugas-tugas mereka.

3) Staf Loyalty dan Retention, sejumlah bukti yang kuat menunjukkan bahwa organisasi yang menerapkan pemberdayaan secara substansial mampu menurunkan labor turnover, meningkatkan produktivitas dan kinerjanya serta pelayanan mereka.

4) The Learning Organization, adalah sesuatu yang membantu individu mengembangkan perubahan yang bermanfaat, dalam hal perilaku dan keahlian. Pem,berdayaan tidak hanya sebagai suatu cara untuk membantu mengarahkan pada learning organization, tetapi merupakan bagian penting dari learning organization. Memberdayakan karyawan seringkali memberikan peran yang secara tradisional tidak terdapat dalam job description mereka, misalnya melatih karyawan lain, memberikan saran pada senior, mengikuti seminar, atau bahkan terlibat dalam riset dan pengembangan.

5) Survival, manfaat terpenting dalam pemberdayaan adalah agar organisasi tetap survive atau lebih kompetitif.

\section{Hubungan Pemberdayaan Dengan Kinerja Karyawan}

Berbagai studi memperlihatkan bahwa ada hubungan positif antara pemberdayaan karyawan terhadap kinerja karyawan.

Wibowo (2008) mengemukakan bahwa : " pemberdayaan meningkatkan percaya diri dalam melakukan sesuatu, yang pada waktu sebelumnya tidak pernah percaya, mungkin dilakukan karyawan bagi organisasi, pemberdayaan akan meningkatkan kinerja organisasi dan individu dapat mengemban bakatnya secara penuh".

Lebih lanjut dikemukakan oleh Thomas dan Velthouse ( 1995 dalam Wibowo, 2007) sebagai peningkatan motivasi tugas intrinsik yang akan menghasilkan kepuasan. Apabila suatu organisasi menjalankan pemberdayaan, di kalangan anggota, organisasi akan tumbuh perasaan menjadi anggota kelompok. Tumbuh perasaan puas dalam mengambil tanggung jawab untuk menjalankan 
tugasnya. Terdapat perasaan bahwa mereka telah melakukan sesuatu yang berharga dan memeroleh kesenangan dalam melakukan komunikasi dan kerja sama dengan orang lain.

Dengan demikian, pemberdayaan meningkatkan percaya diri dalam melalukan sesuatu, yang pada waktu sebelumnya tidak pernah percaya, mungkin dilakukan. Akibatnya akan meningkatkan kepuasan kerja, kerja sama yang lebih dekat dengan orang lain, bekerja dengan tujuan yang jelas, dan mendapatkan prestasi apabila tujuan tercapai. Pengakuan merupakan penghargaan sehingga menyebabkan orang bekerja melihat sinar baru dan lebih menghargai (Wibowo, 2007). 
Pemberdayaan adalah merupakan suatu teknik manajemen sumber daya manusia yang digunakan oleh perusahaan untuk meningkatkan efektivitas organisasi (Conger dan Kanungo, 1989; dalam Debora, 2006). Menurut Kanter ( 1987; dalam Debora, 2006), bekerja dalam kondisi yang diberdayakan memiliki dampak yang positif bagi karyawan, yaitu meningkatkan perasaan keyakinan diri dan kepuasan kerja, motivasi yang lebih tinggi, dan keletihan fisik/mental yang rendah. Situasi kerja yang diberdayakan secara struktural akan lebih besar kemungkinannya untuk memiliki praktek manajemen yang bisa meningkatkan perasaan pekerja tentang kepercayaan pada organisasi dan kepuasan kerja.

Berdasarkan uraian di atas maka penulis dapat mensentesakan bahwa terdapat keterkaitan antara pemberdayaan terhadap kinerja karyawan, apabila program pemberdayaan dilakukan dalam suatu lembaga atau organisasi, maka dapat meningkatkan kinerja karyawan dalam suatu organisasi.

\section{BAB III}

\section{PRAKTEK DI LAPANGAN}

\section{A. Konsep Pengembangan Sumber Daya Manusia}

Perubahan lingkungan yang sangat cepat dan kadang tidak beraturan akibat pesatnya perkembangan teknologi informasi menuntut terbentuknya 'Learning Institutions' yaitu institusi yang responsif terhadap perubahan lingkungan dan secara terus menerus memperbaharui proses pembelajaran dirinya untuk memperbaiki strategi, metode serta mekanisme kerjanya. Hanya dengan dukungan SDM yang Open Mind dan peka terhadap perubahan, suatu institusi dapat menjadi Learning Institution.

Disamping tuntutan perubahan lingkungan, kesadaran untuk segera memberikan prioritas kepada pembangunan SDM berangkat dari kenyataan bahwa institusi tidak akan memiliki keunggulan kompetitif yang unik (Competitive Advantage) jika hanya memusatkan perhatian pada aset-aset non SDM.

Diawal masa tugasnya, SDM dengan latar belakang Pre-entry Education jelas belum memiliki kompetensi dan kapabilitas yang memadai untuk menjalankan tugastugasnya. Untuk mencapai standar kinerja yang memadai dan mempertahankannya diperlukan serangkaian proses pembelajaran yang berkelanjutan. Oleh karena itu program pengembangan SDM (Post Entry Education) harus diarahkan untuk memberikan dasar yang memungkinkan terciptanya long-life learning. 
Sumber daya manusia yang peka terhadap perubahan cenderung memiliki komitmen dan semangat untuk selalu memperbaharui kompetensinya dengan melakukan proses pembelajaran secara terus menerus (Continue Learning) dalam usaha mewujudkan Visi dan Misi institusi.

Perumusan tujuan pengembangan SDM dimulai dengan merumuskan kompetensi yang diinginkan (Desired Core Competence or Capabilites). Istilah kompetensi dan kapabilitas biasa digunakan untuk menggambarkan pengetahuan dan perilaku yang dapat menjadi sumber potensial bagi keunggulan kompetitif sebuah institusi.

Pengembangan kompetensi SDM Universitas Muhammadiyah Bengkulu mencakup tiga komponen utama yaitu :

- Pengetahuan (knowledge), yang meliputi general knowledge, organizational knowledge dan core knowledge.

- Ketrampilan (skills), yang meliputi communication skills, intelectual skills dan interpersonal skills.

- Wawasan (orientation).

Pengembangan perilaku, dititikberatkan pada penanaman nilai-nilai dasar yang dijunjung tinggi di Universitas Muhammadiyah Bengkulu yaitu kesungguhan, keikhlasan dan kebersamaan. Usaha pengembangan perilaku SDM diharapkan akan mendukung terbangunnya budaya institusi yang sesuai dengan Rencana Induk Pengembangan Universitas Muhammadiyah Bengkulu (RIP-UMB).

Kombinasi kompetensi dan perilaku yang sesuai dengan Rencana Induk Pengembangan Universitas Muhammadiyah Bengkulu (RIP-UMB) tentu saja akan sangat mendukung pencapaian visi dan misi Universitas Muhammadiyah Bengkulu.

\section{B. Implementasi Empowerman di Universitas Muhammadiyah Bengkulu.}

Implementasi empowermen di Universitas Muhammadiyah Bengkulu yang penulis jadikan acuan atau indikator pengukuran sudah terlaksana atau belum penulis menggunkan konsep dari Khan (1997) yang menawarakan sebuah model pemberdayaan yang dapat dikembangkan dalam sebuah organisasi. Model pemberdayaan tersebut yaitu: 


\section{Desire}

Tahap pertama dalam model empowerment adalah adanya keinginan dari manajemen untuk mendelegasikan dan melibatkan pekerja atau karyawan.Yang termasuk hal ini antara lain:

a. Pekerja diberi kesempatan untuk mengidentifikasikan permasalahan yang sedang berkembang.

b. Memperkecil directive personality dan memperluas kesempatan kerja.

c. Mendorong terciptanya perspektif baru dan memikirkan kembali strategi kerja.

d. Mengembangkan keahlian team dan melatih karyawan untuk mengawasi sendiri (self control).

Dari indikator di atas sebagian sudah dilaksanakan oleh pimpinan kepada karyawan namum belum secara penuh tanggungjawab. Karyawan sudah diberikan kesempatan untuk mengidentifikasi masalah yang sedang berkembang, namun solusi untuk permasalah tersebut masih belum ada dari pimpinan walaupun sudah diberikan masukan dari karyawan.

Directive personality masih sangat terasa bagi karyawan belum ada kesempatan untuk berkreasi secara luas dan mandiri. Perspektif baru dan strategi kerja sudah diperluas oleh atasan dengan memberikan kesempatan kepada karyawan untuk memikirkan bagaimana strategi yang tepat agar pekerjaan yang mereka lakukan dapat berjalan secara efektif dan efisien. Pengembangan keahlian team bagi karyawan belum berjalan.

Sentesa bagi indikator desire atau suatu keinginan bagi pimpinan untuk memberikan empowermen kepada karyawan di Universitas muhammadiyah Bengkulu belum berjalan sebagaimana yang dikehendaki teori ini, sebab masih banyak yang belum dilakukan oleh pimpinan kreteria empowemen yang sesuai dengan teori ini.

\section{Trust}

Tahap dua adalah membangun kepercayaan antara manajemen dan karyawan Adanya saling percaya di antara anggota organisasi akan tercipta kondisi yang baik untuk pertukaran informasi dan saran tanpa adanya rasa takut. Hal-hal yang termasuk dalam trust antara lain: 
a. Memberi kesempatan kepada para karyawan untuk berpartisipasi dalam pembuatan kebijakan.

b. Menyediakan waktu dan sumber daya yang mencukupi bagi karyawan dalam menyelesaikan kerja.

c. Menyediakan pelatihan yang mencukupi bagi karyawan bagi kebutuhan kerja.

d. Menghargai perbedaan pandangan dan menghargai kesuksesan yang diraih oleh karyawan.

e. Menyediakan akses informasi yang cukup.

Realisasi indikator trust atau kepecayaan yang diberikan pimpinan terhadap bawahan atau karyawan di Universitas Muhammadiyah Bengkulu sudah berjalan dengan baik, sebab pimpinan telah memberikan kesempatan kepada karyawan untuk berpartisipasi dalam pembuatan kebijkan, menyediakan waktu dan sumber daya yang mencukupi bagi karyawan dalam menyelesaikan kerja, menyediakan program pendidikan dan pelatihan kepada karyawan, menghargai perbedaan pandangan dengan karyawan serta menyediakan akses informasi yang cukup kepada karyawan untuk mencapai tujuan organisasi. .

\section{Confident}

Tahap ke tiga dalam proses pemberdayaan adalah menimbulkan rasa percaya diri karyawan dengan menghargai terhadap kemampuan yang dimiliki oleh karyawan. Hal yang termasuk tindakan yang menimbulkan confident antara lain:

a. Mendelegasikan tugas yang penting kepada karyawan

b. Menggali ide dan saran dari karyawan.

c. Memperluas tugas dan membangun jarungan antar departemen

d. Menyediakan jadwal job instruction dan mendorong penyelesaian yang baik.

Implementasi indikator telah melaksanakan empowermen dengan baik adalah menumbuhkan percaya diri setiap karyawan. Sudah terjadi pendelegasian tugas, sudah menghargai ide dan gagasan serta saran dari karyawan. Pimpinan sudah memberikan kesempatan yang luas kepada karyawan untuk mengembangkan diri mereka, memberikan dorongan kepada karyawan untuk melaksanakan tugas dengan baik dan telah merangsang para karyawan untuk berkompetisi dalam melaksanakan tugas mereka 
masing dan diberikan reword bagi mereka yang dapat melaksanakan tugas dengan baik dan tepat waktu.

\section{Credibility}

Tahap ke empat berupa menjaga kredibilitas dengan penghargaan dan mengembangkan lingkungan kerja yang sehat sehingga tercipta organisasi yang memiliki performance yang tinggi. Hal yang termasuk credibility adalah:
a. Memandang karyawan sebagai partner strategis
b. Peningkatan target di semua pekerjaan.
c. Memperkenalkan inisiatif individu untuk melakukan perubahan melalui partisipasi.
d. Membantu menyelesaikan perbedaan dalam penentuan tujuan dan prioritas.

Realisasi indikator empowermen yang berikut ini adalah credibilitas. Indikator ini dengan memandang bahwa karyawan adalah patner kerja. Memadang bahwa karyawan telah melaksanakan tugas sesuai dengan target yang sudah ditentukan. Melakukan perubahan dengan melibatkan karyawan sebagai patner kerja. Menentukan prioritas secara bersama dengan karyawan yang akan melaksanakan tugas tersebut.

\section{Accountabiliy}

Tahap dalam proses pemberdayaan berikutnya adalah pertanggungjawaban karyawan pada wewenang yang diberikan. Dengan menetapkan secara konsisten dan jelas tentang peran, standar dan tujuan penilaian terhadap kinerja karyawan, tahap ini merupakan sarana evaluasi terhadap kinerja dalam penyelesaian dan tanggung jawab terhadap wewenang yang diberikan. Hal yang termasuk dalam accountability antara lain:

a. Menggunakan jalur training dalam mengevaluasi kinerja karyawan.

b. Memberikan tugas dan ukuran yang jelas.

c. Melibatkan karyawan dalam penentuan standar dan ukuran.

d. Memberikan saran dan bantuan kepada karyawan dalam menyelesaikan beban kerjanya.

e. Menyediakan periode dan waktu pemberian feedback.

Realisasi empowermen untuk inndikator ini sudah dapat dilaksanakan dengan baik antara pimpinan dan karyawan. Evaluasi kinerja karyawan sudah berjalan dengan baik. 
Uraian tugas cukup jelas dan transpran. Standar kerja jelas berdasarkan uraian pekerjaan yang diberikan kepada masing-masing karyawan. Pimpinan sudah memberikan arahan dan bantuan kepada karyawan dalam melaksanakan tugas yang diberikan kepada karyawan. Sudah ada feedback kepada atasan berupa penilaian yang diberikan oleh para karyawan terhadap atasan.

\section{Communication}

Tahap ini merupakan tahap terakhir, diharapkan adanya komunikasi yang terbuka untuk menciptakan saling memahami antara karyawan dengan manajemen. Keterbukaan ini dapat diwujudkan dengan adanya kritik dan saran terhadap hasil dan prestasi yang dilakukan pekerja. Hal yang termasuk dalam commnication antara lain:

a. Menetapkan kebijakan open door communication.

b. Menyediakan waktu untuk mendapatkan informasi dan mendiskusikan permasalahan secara terbuka.

c. Menyediakan kesempatan untuk cross training. maupun operasional.

Komunikasi antara karyawan dengan pihak pimpinan sudah berjalan baik. Kebijakan yang ditetapkan sudah dikomunikasikan terlebih dahulu kepada seluruh karyawan. Antara pimpinan dan karyawan sering sharing pendapat untuk memecahkan permasalahan yang dihadapi bersama yang berhubungan dengan organisasi. Kotak saran untuk kemajuan organisasi teredia. Diskusi sering dilakukan dalam rangka membangun komunikasi antara pimpinan dan karyawan.

\section{Kinerja Karyawan Universitas Muhammadiyah Bengkulu}

Untuk merlihat kinerja karyawan suatu organisasi menurut John Boureau, (1997) dapat dilihat dari elemen-eleman kinerja karyawan yaitu:

1. Quantity of work

2. Quality of work

3. Compatibility with others

4. Presence at work

5. Length of service

6. Flexibility 
Untuk melihat kinerja karyawan pada Univesitas Muhammadiyah Bengkulu, penulis akan menggunakan indikator ini, karena indikator ini dapat disedehanaan lagi menjadi:

\section{Rutinitas dalam bekerja}

a. Karyawan selalu memperbaiki pekerjaan yang telah dikerjakan.

b. Hasil kerja karyawan selalu memenuhi tuntutan kualitas yang telah ditentukan

c. Keterbatasan fasilitas kerja selalu mengganggu kelancaran menyelesaikan pekerjaan.

d. Koordinasi pekerjaan selalu dilaksanakan

e. Karyawan menggunakan bahan kerja sesuai dengan yang telah ditentukan.

\section{Rasa suka menolong}

a. Atasan mengakui hasil kerja karyawan sehingga berusaha menjaga kualitas pekerjaan yang diberika.

b. Keterbatasan dana tidak menjadi hambatan dalam melakukan kegiatan yang berhubungan dengan tugas.

c. Menyelesaikan pekerjaan sebelum batas waktu yang telah ditetapkan.

d. Bekerja teliti untuk kepentingan organisasi.

\section{Fleksibel terhadap pekerjaan}

a. Setiap tugas dari atasan dikerjakan langsung oleh karyawan tanpa menunda pekerjaan tersebut.

b. Karyawan meninggalkan kantor dengan target hasil pekerjaan sudah tercapai.

c. Fokus pada hasil kerja yang ingin dicapai.

d. Meminta kepada atasan untuk memberikan rekan kerja.

e. Berangkat kerja lebih awal.

f. Pulang kerja setelah jam kantor usai.

g. Menginformasikan kepada atasan jika berhalangan hadir kerja.

h. Berkoordinasi dengan rekan kerja.

\section{Pengakuan atas hasil kerja}

a. Selalu mencapai target kerja.

b. Menyelesaikan pekerjaan tepat waktu 
c. Menyelesaikan pekerjaan sesuai dengan target.

d. Berkerjasama dengan rekan kerja.

e. Mendapat pujian atasan atas pekerjaan.

f. Hasil kerja diakui sesama rekan kerja.

Dari uraian perindikator di atas dapat penulis sintesakan bahawa kinerja karyawan Universitas Muhammadiyah Bengkulu, sudah cukup baik karena telah melaksanakan tugas sesuai dengan program kerja yang telah ditetapkan. Kualitas kerja sesuai dengan tuntutan pekerjaan yang dibebankan kepada karyawan. Kuantitas kerja sesuai dengan pekerjaan rutin yang ditugaskan kepada masing-masing karyawan. Sudah melaksanakan tugas secara terkoordinasi antara sesama rekan kerja. Sehingga atasan memberikan pujian atas pekerjaan yang telah dikerjakan.

\section{BAB IV}

\section{ANALISIS MASALAH}

Peran sumber daya manusia pada hakekatnya merupakan salah satu modal dan memegang kedudukan yang paling penting dalam mencapai tujuan perusahaan. Oleh karena itu perusahaan perlu mengelola dan memelihara sumber daya manusia yang ada didalam perusahaan untuk menjadikannya sebaik mungkin. Karena untuk mencapai kesuksesan suatu perusahaan bukan hanya dalam keunggulan teknologi saja, namun peran sumber daya manusia merupakan komponen terpenting dalam mencapai kesuksesan perusahaan.

Dari uraian di atas dapat penulis jelaskan bahwa untuk meningkatkan kinerja karyawan di Universitas Muhammadiyah Bengkulu, dipandang perlu meningkatkan peran kinerja sumber daya manusaia yang tergabung di dalam organisasi ini, agar permasalahan sumber daya manusia dapat terselesaikan dan dapat berkerja dengan efektif dan efisien.

Dalam meningkatkan kinerja karyawan agar lebih baik dalam suatu perusahaan perlu dilakukan hal-hal yang bisa meningkatkan kinerja seorang karyawan, Salah satunya adalah pemberdayaan karyawan. Karena pemberdayaan karyawan merupakan upaya mendorong dan memungkinkan individu-individu untuk mengemban tanggung jawab pribadi atas upaya mereka memperbaiki cara mereka melaksanakan pekerjaanpekerjaan mereka dan menyambung pada pencapaian tujuan-tujuan organisasi. Oleh karena itu sering kali jalan yang ditempuh oleh perusahaan untuk meningkatkan 
kinerja karyawan, motivasi, komitmen, dan produktivitas karyawan adalah melalui pemberdayaan karyawan. Clutterluck (2008)

Pemberdayaan karyawan yang dilakukan oleh perusahaan kepada karyawannya bisa memacu untuk meningkatkan kreatifitas, motivasi dan daya inovatif yang dimiliki oleh setiap karyawan dalam melaksanakan tugas dan tanggung jawabnya. Dengan adanya program pemberdayaan karyawan, kinerja karyawan akan meningkat. Sehingga tujuan perusahaan akan tercapai dengan baik, cepat dan fleksibel.

Selain pemberdayaan karyawan dalam meningkatkan kinerja dari setiap karyawannya, adalah kompensasi yang diberikan oleh perusahaan kepada setiap karyawannya. Kompensasi dapat meningkatkan prestasi kerja dan memotivasi karyawan. Oleh karena itu perhatian organisasi atau perusahaan terhadap pengaturan kompensasi secara rasional dan adil sangat diperlukan. Bila karyawan memandang pemberian kompensasi tidak memadai prestasi kerja, motivasi maupun kepuasan kerja mereka cenderung akan menurun. Samsudin, Sadili, (2006). Oleh karena itu kompensasi yang diberikan kepada setiap karyawan haruslah sebanding dengan kontribusi yang telah diberikan oleh karyawan terhadap perusahaan.

Kinerja merupakan hal yang penting yang harus dicapai oleh setiap perusahaan dimanapun termasuk di Universitas Muhammadiyah Bengkulu, karena kinerja merupakan cerminan dari kemampuan perusahaan dalam mengelola dan mengalokasikan sumber dayanya. Febryani (2003). Setiap perusahaan selalu berupaya untuk meningkatkan kinerja karyawannya, karena dengan kinerja karyawan yang baik tujuan perusahaan akan tercapai dengan baik sesuai yang diharapkan, begitu pula sebaliknya jika kinerja karyawan buruk maka tujuan perusahaan tidak akan tercapai dengan baik.

Universitas Muhammadiyah Bengkulu sebagai salah satu Perguruan Tinggi Swasta selalu berupaya untuk meningkatkan permasalahan yang berhubungan dengan empowermen dan kinerja. Karena semakin baik empowermen yang diberikan oleh atasan kepada bawahan atau karyawan maka akan semakin meningkatkan kinerja karyawan pada Universitas muhammadiyah Bengkulu. Empowermen merupakan suatu keinginan dan kepercayaan antara pimpinan dan karryawan. Jati diri karwayan akan semakin terlihat apabila empowermen yang diberikan semakin besar, dan begitu juga sebaliknya empowermen dapat menjadi penghabat untuk meningkatkan kinerja 
karyawan jika tidak dilakukan upaya pemberian empowermen yang besar baik dan benar.

\section{BAB V}

\section{SARAN PEMECAHAN MASALAH}

Berdasarkan praktek dilapangan dan analisis pemecahan masalah di atas, maka dapat penulis sarankan untuk pemecahan masalah yang berhubungan dengan empowermen dan kinerja karyawan pada Universitas Muhammadiyah Bengkulu sebagai berikut :

1. Untuk meningkatkan empowermen yang sudah terjalin selama ini, kiranya pimpimpinan lebih memperhatikan apa yang menjadi keinginan dan kemauan karyawan dalam melaksanakan tugas mereka sehari-hari.

2. Untuk memberikan kepercayaan kepada karyawan dalam melaksanakan tugas secara penuh, agar mereka merasa mempunyai acountability dan responsibility terhadap lembaga dimana mereka bekerja.

3. Menimbulkan rasa percaya diri karyawan dengan menghargai terhadap kemampuan yang dimiliki oleh karyawan.

4. Menjaga kredibilitas dengan penghargaan dan mengembangkan lingkungan kerja yang sehat sehingga tercipta organisasi yang memiliki performance yang tinggi.

5. Memberikan pertanggungjawaban karyawan pada wewenang yang diberikan. Dengan menetapkan secara konsisten dan jelas tentang peran, standar dan tujuan penilaian terhadap kinerja karyawan, dan merupakan sarana evaluasi terhadap kinerja dalam penyelesaian dan tanggung jawab terhadap wewenang yang diberikan.

6. Adanya komunikasi yang terbuka untuk menciptakan saling memahami antara karyawan dengan manajemen. Keterbukaan ini dapat diwujudkan dengan adanya kritik dan saran terhadap hasil dan prestasi yang dilakukan pekerja.

7. Agar Karyawan selalu memperbaiki pekerjaan yang telah dikerjakan secara rutin.

8. Agar karyawan melakukan pekerjaan dengan kualitas yang utama dan kuantitas yang telah ditetapkan oleh organisasi. 
9. Meningkatkan semangat kerja karyawan dengan cara membangkitkan rasa tolong-menolong sesama rekan kerja

10. Agar selalu berkoordinasi dalam melaksanakan pekerjaan baik kepada sesama rekan kerja maupun kepada atasan.

11. Agar selalu bekerja tepat waktu yang telah ditetapkan.

12. Jangan menunda pekerjaan yang sudah menjadi tanggungjawab.

13. Memberikan pelayanan yang prima kepada siapa saja yang membutuhkan jasa pelayanan.

14. Budaya senyum dalam memberikan pelayanan

\section{BAB VI}

\section{KESIMPULAN}

Dari uraian-uraian yang telah dijelaskan di atas maka dapat penulis simpulkan sebagai berikut:

1. Implementasi empowermen di Universitas Muhammadiyah Bengkulu sudah dilakukan cukup baik, yang berhubungan dengan:
a. Desire (Keinginan)
b. Trust (Kepercayaan)
c. Confident (Percaya diri)
d. Credibility (Kredibilitas)
e. Accountability (Pertanggungjawaban)
f. Communication (Komunikasi)

2. Kinerja Karyawan sudah cukup baik hal ini dapat dilihat dari:
a. Quantity of work
b. Quality of work
c. Compatibility with others
d. Presence at work
e. Length of service
f. Flexibility

3. Empowermen dapat meningkatkan kinerja karyawan jika dilakukan dengan sungguh-sungguh baik dan benar. 


\section{Referensi}

Armstrong, Michael. Performance Management Key Strategies and Practical Guidelines, ;tri Edmon. London: Institute of Personnel and Development, 2006.

Blanchard, Kenneth H. dan Paul Hersey. "Revisiting the Life-Cycle Theory of Leadership" Journal Training \& Development, EBSCO Publishing edisi Januari, 1996.

Colquitt, Jason A, Jeffery A LePine dan Michael J. Wesson. Organizational Behavior: Improving Performance and Commitment in the Workplace. New York: McGraw-Hili, 2009.

Debora, Pengaruh Pemberdayaan Psikologis dan Kerja terhadap Kepercayaan Organisasional dan Kepuasan Kerja Dosen Tetap Perguruan Tinggi Swasta, Jurnal Manajemen dan Kewirausahaan, Vol. 8, No. 2. 2000.

Duvall, C. K. Developing individual freedom to act empowerment in the knowledge organization. Participation and Empowerment (An International Journal), Volume 7, No. 8, pp. 204-212. 1999.

George, Jennifer M. dan Gareth R. Jones. Understanding and Managing Organizational Behaviour, 4thEdition. New Jersey: Pearson Prantice Hall,2005.

Ivancevich, John M., dan Michael T. Matteson. Organizational Behavior And Management, a'h Edition. Boston: McGraw-Hili, 2008.

Khan, Sharafat, They Key to being a Leader Company: Empowerment, Journal Personality and Partisipation, p.44-45. 1997,

Kondalkar, V. G. Organizatio'nalBehavior. New Delhi: New Age International (P) Limited, Publishers Ansari Road, Daryaganj, 2007

Luthans, Fred. Organizational Behavior Eleventh Edition. Singapore: McGraw-Hili International Edition, 2008.

Mahardian, Faktor-faktor yang Berpengaruh Terhadap Pemberdayaan di RS Roemani Semarang, Tesis Program Pascasarjana Magister Manajemen UNDIP (tidak dipublikasikan). 2004,

Mulyadi. Sistem Perencanaan dan Pengendalian Manajemen (edisi.3). Salemba Empat, Jakarta. 2007.

Mangkunegara, Anwar Prabu, Manajemen Sumber Daya Manusia Perusahaan, Remaja Rosdakarya, Bandung. 2013. 
Sadarusman, Eka, Pemberdayaan: Sebuah Usaha Memotivasi Karyawan, Fokus Ekonomi, Vol. 3, No.2. 2004,

Sariyathi, N. K. "Prestasi Kerja Karyawan: Suatu Kajian Teori." Buletin Studi Ekonomi, Volume 12, Nomor 1, Tahun 2007.

Sondang P. Manajemen Sumber Daya Manusia, Edisi ke 1 Cetakan Ketiga, PT Bima Aksara,Jakarta. 2001.

Suwatno dan Donni Juni Priansa. Manajemen SDM dalam Organisasi Publik dan Bisnis, Cetakan Kedua, Alfabeta, Bandung. 2011

Timpe, A. D. Kinerja. Jakarta: Elex Media Komputindo, 2000.

Thomas, K. W., Velthouse, B.A, , Cognitive Elements of Empowerment: an Enterpretative Model of Intrinsic Task Motivation, Academy of Management Review, Vol:15, p: 4-666. 1990

Wibowo, Manajemen Kinerja, Jakarta: PT Grafindo Persada. 2007. 